\title{
Lviv and Chernivtsi: Two Memory Cultures at the Western Ukrainian Borderland
}

\author{
Eleonora Narvselius \\ Centre for European Studies, Lund University, Sweden \\ Niklas Bernsand \\ Centre for European Studies, Lund University, Sweden
}

\begin{abstract}
Despite geographical proximity and comparable historical development since the fall of the Soviet Union, Lviv and Chernivtsi betray different approaches to commemorating the past. This might point to the existence of different cultures of memory that sustain a narrative about acceptance or rejection of ethnic diversity. But the cultures of memory in the cities also have common characteristic, namely, contemporary urbanites form their attitudes towards the past not through personal experience and family transmission of past memories but through prosthetic memory, which relies on hearsay, media, literature, popular culture and the arts. When deliberate choice comes to the fore in building various identity projects, the work of stitching together contradictory historical representations is guided not so much by path-dependent logic of collective memory as by present-day expediency and power games of different mnemonic actors. Therefore, this paper argues that the most observable trend in the cultures of memory in Lviv and Chernivtsi is pillarization, i.e., an agreement among external and internal memory entrepreneurs and marketeers that each population group is the custodian of its "own" heritage. Nevertheless, ultimately the condition of heritage envisioned in the two cities seems to be an assimilationist "incorporation-to-the-core" model, where the core consists of various versions of the Ukrainian national heritage.
\end{abstract}

Keywords: Memory cultures, prosthetic memory, built environment, identity.

0 ver the past two decades ideas about the global, cosmopolitan (Lévy and Sznaider; Misztal), transcultural, and multidirectional (Rothberg) dimensions of collective memories have gained broad acceptance in Memory Studies. Increasingly, this cross-disciplinary field searches for its objects of study among either transcultural, entangled (Feindt, Krawatzek et al. 24-44) and remediated representations of the past, or in diffuse communities of memory located in borderlands, regions, cities and subcultures. Aside from the urge to overcome constrains of "methodological nationalism," one may distinguish at the core of these recent shifts in Memory Studies changing conceptualizations of place and space. Space is envisioned not only as a material, naturally bounded continuum; it is viewed as shaped by action, remediation, imagination, performance and 
constant redefinition of borders in practices of various actors-both those driving official memory politics and those influencing memory cultures in a less conspicuous manner (Aronsson 16; Certeau; Erll 2011). Urban spaces analyzed here perfectly exemplify this view.

Lviv and Chernivtsi are located not far from one another in what is now Western Ukraine and have been subjected to similar political-historical processes, cultural influences and transnational ideational trends. Moreover, their present architectural environment and the vicissitudes of their demographic composition bear much resemblance. What has puzzled us was that since the fall of the Soviet system these two cities expose significantly different patterns of commemoration and practices with regard to the past. These differences may be observed, in particular, in the built environment and tangible markers of heritage and "usable pasts" in the public spaces. Arguably, this may indicate a presence of different contemporary memory cultures whose features, on the one hand, might have been traced to earlier historical processes, but, on the other hand, have been formed by the post-1989 political-cultural agendas. Hence, the main challenge of our research has been to point out possible causes of this difference and analyze how memory cultures of these cities-far from being confined to a robust national (Ukrainian) frame of reference-are presently shaped by different cultural-political and performative contexts.

By way of introduction to our findings, we will first explain the choice of analytical perspective. We will then address the recent theoretical approaches to the specificity of Eastern European mnemonic spaces that the urban cultures of the chosen cities are a part. After presenting examples of varying public expressions of collective memories in Lviv and Chernivtsi, we will shift the perspective from mnemonic performances to construction of heritage in the two cities. This will allow us not only to point out differences, but also to adequately address resemblances of the urban memory cultures.

\section{SCRUTINIZING THE THEORETICAL FOCUS: MEMORY CULTURES, PERFORMATIVITY OF CULTURAL MEMORIES, POSTMEMORY AND PROSTHETIC MEMORY}

Throughout our project, ${ }^{1}$ we have tried to make sense of the complex interplay between the palimpsest-like built environments typical of Eastern

\footnotetext{
1 This article is the result of an international project, titled "Memory of Vanished Population Groups and Societies in Today's East-Central European Urban Environments. Memory Treatment and Urban Planning in Lviv, Chernivtsi, Chisinau and Wrocław." The project is supported by the Bank of Sweden Tercentenary Foundation and affiliated with Lund University.
} 
European urban milieus, marked by "dismembered multiethnicity" (Follis 181), and the contemporary urbanites' popular knowledge about the prewar urban populations who created these milieus, but perished during and in the aftermath of World War II. Using vantage points developed within Memory Studies, we have been primarily interested in how clues provided by present-day cultural environments correlate with identityforming knowledge about the past (Assmann J. 2010, 123; Kansteiner 17997; Radstone and Hodgkin), often referred to as cultural or collective memories. The complex interplay of identities, localities and memories has been conceptualized in a variety of ways (e.g, Olick; Kansteiner 179-97; Confino; Sherlock). For the purposes of this study, we nevertheless lay emphasis on memory cultures (or, in some formulations, cultures of remembrance) and cultural/collective memories.

Following Jeffrey Olick's (91) general recommendation to abstain from viewing collective memory "as an independent or dependent variable, a thing determined or determining," we do not regard material urban milieus as direct manifestations of cultural memories. Instead, we suggest that cultural contexts, material milieus and symbolic entanglements may be outcomes, resources, constraints and triggers of cultural memories. Material environments of cities are complex products of practices and ideologies, which actualize cultural memories of constantly changing urban communities in a myriad of ways. We do acknowledge, however, that it makes sense to talk about different memory cultures unfolding on the scale of the two cities, although not confined to their boundaries, since physical cityscapes do not always coincide with memoryscapes (Basu 116-117; Phillips and Reyes). The latter ones extend to the material memorabilia, cultural imaginings and practices of several generations living not only in Lviv and Chernivtsi, but dispersed all over the world and identifying with the powerful myths of these two cities. The memory cultures hence may be analytically distinguished as patterns of memory work formed among local, national and transnational actors whom one may call commemorative entrepreneurs (Mink 469-90). In this study we approach commemorative practices and knowledge of the past as performed in Lviv and Chernivtsi by several actors who presently inhabit and transform the cityscapes and memoryscapes of these cities. We see no clear causality between cultural memories and cultures of remembrance as a product of preexisting communities with more or less fixed identities, but rather admit their ambiguous relation that changes, depending on changing analytical perspectives.

The processual nature of memory (Olick; Winter 11-34) evokes the idea of mnemonic performativity. Remembrance is performative rather than simply reproductive, as "when we come together to do the work of 
remembrance, the story we fashion is different from those that have come before" (Tilmans, van Vree and Winter 7). Hence, the past is constantly affirmed and transformed through practices of collective remembrance. The performative aspect of cultures of remembrance is underpinned by "imaginative investment, projection, and creation" (Hirsch 107) presented by memory actors. In our opinion, varying grades and forms of such "imaginative investment, projection, and creation" of memories about the urban past enacted by both local and external elites, urban populations, and mnemonic activists, make mnemonic landscapes of Lviv and Chernivtsi dissimilar. As will be demonstrated later, while the "burden of the past" (exemplified by historical narratives and architectural environment) is largely comparable in these two cities, the "choice of the past" - charged with interests, emotions and imagination of the contemporary mnemonic entrepreneurs-is what makes the difference. Or, using an apt metaphor from Aleida Assmann (2), while Lviv and Chernivtsi are haunted by similar ghosts of the past, they purposefully seek contact with different spirits of the past.

Choice brings the issue of diversity, intentionality and contingency into the picture. Populations and societies affected by the same historical processes, political regimes and global trends may accumulate essentially different memories and present them in the public sphere in different ways. The public space is typically saturated with multiple symbolic meanings materially represented in architecture, urban toponyms, infrastructure for public meetings, and visual signals (advertisements, decorations etc.). The semiotic complexity of public spaces in our two cities has resulted not only from the rich urban history, with various groups constantly making claims to, and negotiating in, the public space, but also from drastic exclusions and inclusions of whole peoples with their cultural hallmarks. By and large, it challenges the idea of essentially static and bounded mnemonic communities as generators of more or less homogeneous collective memories. Hence, taking the vantage point of our study, there is a danger of reification and simplification were we to derive collective memories from big imagined communities such as nations, or if we were to talk about certain cultures of remembrance as "typical" of particular urban communities.

Almost 70 years after the events that stripped Lviv and Chernivtsi of most of their prewar populations, descendants of Soviet newcomers-much like today's descendants of prewar urbanites that live mainly abroad-have neither first-hand personal memory of these dramatic events nor of the way of life that preceded them. In this respect, these two important groups of memory actors-who currently commission monuments, organize commemorative events and make efforts to preserve memories about the 
former historical periods and former inhabitants-are in the same situation. Both actively "choose" the past they strive to elucidate and reenact. They both perform collective memories in order to "express or embody or interpret or repeat a script about the past" (Winter 11). Both are involved in "imaginative investment, projection, and creation" (Hirsch 107) of the past. Nevertheless, the sources of their creative work, second-hand knowledge and emotional attachment to the past, are different. Typically, the offspring of the older population groups rely on family archives and personal stories of relatives, while the children of the newcomers extract their knowledge about the past primarily from much more fragmentary and impersonal sources that do not speak for themselves (e.g., architectural environment, interiors, artifacts, and literary references). ${ }^{2}$ The difference between these two types of memory work may be conceptualized in terms of the difference between postmemory (an afterlife of "living" memory of witnesses shared across generations of "legitimate custodians") and prosthetic memory (a reconstructed past, from the position of emotional and aesthetical distance, that neither a person nor her relatives experienced). Prosthetic memories are generated not within families, but rather through accessible public domains such as literature, film, museums and theatres. They are "transportable and therefore challenge more traditional forms of memory that are premised on claims of authenticity, "heritage," and ownership" (Landsberg 3). Combinations of both types of memory work in Lviv and Chernivtsi are especially evident in connection with public commemorative initiatives and symbolic marking of public urban spaces. Without denying that oftentimes "[g]uilt, resentment, denial, powerful political taboos, and the imperative of dealing with the national trauma all combined to block the formation of memory of vanished others" (Blacker 178), we would however like to add that the modality of collective memory work in the postwar urban environments in Eastern Europe has not only its limitations, but also peculiar (see Judt 172; Blacker and Etkind 6-9) and enabling qualities.

In order to understand the logic behind the "choices of the past" made by present-day urbanites, one needs to look closer at what (or whose) heritage is promoted, mediated and reenacted. A defining characteristic of

\footnotetext{
${ }^{2}$ In should be emphasized that experience-based communicative memories about prewar life and the events of World War II are still conveyed from the older to the younger generation in Lviv and Chernivtsi. Unlike Kaliningrad or Wrocław, the two Ukrainian cities retain a statistically significant part of the prewar populationUkrainians and Poles in Lviv; Ukrainians and Romanians in Chernivtsi, as well as smaller groups, such as Jews, Germans and Armenians-although descendants of newcomers make up the largest part of today's urbanites in both cities.
} 
heritage is that it selects and estimates fragments of the past from the perspective of present-day concerns and values promoted in the public sphere (Graham and Howard 2-15; Peckham 1-16). In the course of defining a heritage, historical knowledge and collective memories become not only an issue of diffuse opinion formed by various actors, but also a potential zone of interpretative uncertainties and conflicts. As we will argue in the concluding part of the article, despite differences in form and content of the "imaginative investment, projection, and creation" of the urban past, Lviv and Chernivtsi have been arenas of similar heritage policies, characterized by gradual assimilation of multicultural difference into the national core.

\section{SIMILARITIES OF THE URBAN MEMORY CULTURES IN LVIV AND CHERNIVTSI}

Built environments, memory cultures and historical narratives of the two western Ukrainian cities expose many similar features, which may be attributed to the periods of common history in the same states, embeddedness into the same type of political structures, and openness to similar transcultural ideological trends. As a result, several common "points of crystallization" (Assmann J. 2011, 24) of collective memory emerged that supposedly preconditioned a similar path-dependent logic of local memory cultures in Lviv and Chernivtsi. Our impression, to put it in sociological terms, is that one can distinguish analytically identical variables in the cultures of remembrance in these cities, but that the values of these variables are different in each case. The narrative being transmitted within and through the urban cultures of remembrance is akin to pendulum movement between diversity and homogeneity, between various types of acknowledgement and denial of ethno-cultural and religious diversity throughout the course of history.

Lviv and Chernivtsi have been borderland urban centres, being on the frontline of both eastward, westward, southward and northward expansion of several powers operating in Europe (Austria, Poland, Germany, the Ottoman Empire, the Russian Empire, the USSR and, in a sense, the EU). Historical and socio-political transformations (often drastic and catastrophic) have been reflected not only in the shifting borders of empires, nation states and regions, but also in the changing demography of urban settings. Both Lviv and Chernivtsi date back to medieval times and initially belonged to the Principality of Galicia-Volhynia and the Principality of Moldavia, although Chernivtsi remained small and saw significant urban development primarily in the $19^{\text {th }}$ century during Habsburg rule. Although the ethnic composition of the city changed in different historical periods, a specific premodern pattern of ethnic and religious groups characterized Lviv even in the era of national states and their accompanying cultural 
homogenization. This was marked by the visibility of population groups with developed transnational connections, such as Jews, Armenians and the German-speaking peoples (Czaplicka 13-47; Ther 251-84; Hrytsak 2005, 185-209). The population of premodern Chernivtsi, which emerged as a toll-station and market place, was mainly composed of Romance- and Eastern Slavic-speaking Orthodox Christians (i.e., ancestors of modern Ukrainians and Romanians) as well as Orthodox Jews.

Conflation of these medieval patterns of diversity with more modern forms of ethno-cultural self-organization became a hallmark of the multiethnic Habsburg Empire. As capitals of the Habsburg provinces Galicia and Bukovina, Lviv and Chernivtsi gained prominence as cultural centres. In the second half of the $19^{\text {th }}$ century cultural transference from Lemberg to Czernowitz become evident in literature, music and theatre (see Lihaciu). The cities also became subject to massive rebuilding and modernization, and their present-day historic centres maintain much of the stylistically distinct architecture typical of the Habsburg period. After being partially silenced and partially distorted by Soviet historical narratives, the story of the Dual Monarchy emerged in the post-Soviet period as an embodiment of a golden age in the public spaces of Lviv and Chernivtsi. The enthusiastic response of the cultured classes as well as consumers of mass culture to the "Habsburg myth" became evident in Western Ukraine at the end of the 1990s (Zayarniuk 15-17). Imagining Habsburg rule as a golden age in the history of Northern Bukovyna and Galicia indicates, on the one hand, a strong post-1991 reaction against Soviet ideological constructions of historiography and mass culture and, on the other hand, the rehabilitation of the poly-ethnic heritage of the region, which in both cities occurred in parallel with an ethno-cultural Ukrainian revival within an independent Ukraine. Despite the generally positive connotations of the Habsburg myth, especially given its potential to boost political, economic and cultural connections to Central Europe, the attitude toward this period in the two cities is nuanced and in some respects dissimilar. This is especially evident in commemorative initiatives and public discussions. Hence, while being a uniting "point of crystallization," (Assmann J. 2011, 24), references to the Habsburg period also expose differences in present-day cultures of remembrance and public imagery (more about this below).

During the Habsburg period and also during the interwar decades, Lviv and Chernivtsi retained their traditional demographic composition and multicultural ambience. Nevertheless, this situation began to erode slowly already in the 1930s as a result of the strong assimilatory policies of the Polish and the Romanian states. In Chernivtsi, the Polish population diminished greatly during the Romanian period as a result of out-migration 
to Poland. However, the older patterns of ethnic diversity changed drastically and irrevocably as a result of World War II. In Chernivtsi, most of the Germans were evacuated to Germany, while a large number of local Jews were murdered and most of those who survived were expelled from the city in the aftermath of the war (Frunchak 442-43). Many Romanians fled or were deported to the east by the Soviets. A similar fate befell urban Ukrainians (i.e., those who identified with the Ukrainian nationalist political cause) and many local Armenians. The population of the city was thus radically transformed. Lviv faced catastrophic change in its urban demography following the brutal Sovietization of 1939-1941, the exterminatory policies of the Nazis of 1941-1944 and the wide-scale postwar repressions, expulsions and population exchanges. According to different estimates, after World War II only 10 to 20 percent of Lviv's prewar population remained (Hrytsak 2002, 58-59). Of the 160,000 Jews who had been registered in Lviv before the Wehrmacht occupationmaking up around one third of the city's population-only about 2000 survived the Holocaust (Ther 271). The great majority of Poles who made up more than a half of Lwów's population in 1939 disappeared from the city during the course of the war and the several waves of subsequent expulsions organized by Soviet authorities when the eastern territories of Poland were re-annexed by the USSR in 1944.

As a result, considerable numbers of postwar populations in both cities had no urban cultural roots in their new place of settlement. They came either from the surrounding ethnically Ukrainian countryside or, in the case of Chernivtsi, from Romanian rural areas, as well as from other parts of Soviet Ukraine, from Russia or from the newly incorporated Moldavian SSR. Ethnic groups that earlier had key positions in the political, cultural and economic development of these towns were now absent or represented only partially. The new population structure was, however, by no means monoethnically Ukrainian. The demographic weight of ethnic Russian was especially significant during the first postwar decades. In the case of Chernivtsi, Russian-speaking Jewish migrants from other parts of the USSR played a major role.

The extinction of the prewar polyethnic urban cultures, combined with huge human losses as a result of the clash of two totalitarian systems and the implementation of detrimental civilizing/modernizing projects, allows us to speak about Lviv and Chernivtsi as typical examples of the EastCentral European Bloodlands (Snyder). The fate of the prewar urban worlds-stripped of their ethno-cultural diversity because of the Holocaust, communist repressions, wartime ethnic cleansings, and postwar expulsions-exemplify the scope of the tragic historical experiences that 
inscribe the Eastern European borderland cities of Lviv and Chernivtsi into the "seven circles of European memory" 3 (Leggewie).

With Ukraine's independence in 1991 a new "point of crystallization" begins in the history of Lviv and Chernivtsi, marked by growing interest in issues of prewar ethno-cultural diversity, cultural heterogeneity and transcultural connections. Envisioning a multicultural heritage, in line with contemporary (primarily "Western") models, became a part of post-Soviet "normalization." The Soviet legacy of silencing the historical presence of a range of nationalities (Jews, Poles, Romanians, Austrians, Germans) and negligence of their cultural heritage undoubtedly left its traces (Bartov; Risch). The imperative of forming a new national narrative from the Ukrainian perspective has also contributed to ambivalence about memories of the "others." Nevertheless, the new European and global strategies of addressing the difficult pasts, acknowledging "otherness" and promoting cultural contacts across borders have also had significant impact on the politics of memory as well as on popular attitudes. Due to efforts of local elites, parts of the historical centres of Lviv and Chernivtsi have been included in the UNESCO Heritage List of 1998 and 2013 respectively. Ethnic diversity and the rich architectural heritage of several nations were especially emphasized as the reason for adding the cities to the List. While memory landscapes remain divided and segregated in many respects, the cultural diversity and legacy of the prewar urbanites have nevertheless been acknowledged locally and, moreover, turned into a resource for various political, commercial and cultural initiatives.

\section{DIFFERENT TREATMENT OF SIMILAR MNEMONIC REFERENCES IN LVIV AND CHERNIVTSI}

With Ukraine's independence, the collective memories about the $20^{\text {th }}$ century of present-day residents of Lviv and Chernivtsi became informed, largely, by "three C's": canonization of the national order of things; commercialization of the cityscape; and efforts to eliminate vestiges of the colonial condition. However, the significance of the "three C's" varies in each city. Bearing this in mind, and also referring to the theoretical framework that was outlined earlier, we will present several examples of how memories are performed (i.e., actively chosen, presented, enacted, and

\footnotetext{
${ }^{3}$ Claus Leggewie argues that the main topics of supra- and transnational memory in present-day Europe may be presented as concentric circles, with the Holocaust as the "negative founding myth" at the core. Other hallmarks include Soviet Communism, expulsions, the genocide of Armenians, the history of warfare, migrations-and the success story of the EU.
} 
transformed) in relation to several historical periods that characterize attitudes toward diversity.

In terms of the pendulum metaphor mentioned above, i.e., the movement between acknowledgement and denial of ethno-cultural diversity in the course of history, the Soviet period occupies an intermediate position. The USSR's nationality policies after World War II were full of contradictions. Despite their ultimate ideological goal of creating a Soviet man, they still left sufficient room for the expression of ethnic and national difference (Slezkine; Martin). Nevertheless, ideological decisions and mismanagement of the urban space led to negligence, erasing of most remnants of prewar "otherness" that had been still visible in the postwar cityscapes of Lviv and Chernivtsi.

In Lviv, large-scale plans of radically reshaping the city centre, suggested in the first postwar decade by Soviet architects, were never implemented (Tscherkes 205-222). Instead, superficial adjustments (e.g., dismantling of prewar monuments, plaques, decorations) and changes of function (most often, by turning sacral buildings into stores or workshops) continued to prevail in the historic centre, while the "Soviet style" affected the new housing and the industrial districts. In 1975-1991 the city's wellpreserved medieval downtown was taken under state protection and declared a historical-architectural site. Promotion of the medieval period was instrumental in highlighting the historical architecture that could now be classified as early Ukrainian and, hence, supported the officially sponsored narrative of Lviv as an ancient Ukrainian city. Meanwhile, an array of valuable landmarks, testifying to the historical presence (and dominance) of other peoples, was left outside the zone of protection. Among them were, for instance, nineteenth-century buildings that followed broader Austrian and European architectural trends and could be construed as part of Polish, Austrian, Jewish, and Ukrainian cultural legacies (Prokopovych 1-18). Important symbols of Soviet power became subject to memory politics: new street names, the Lenin monument and several memorial places devoted to the Great Patriotic War (the Hill of Glory, the Soviet tank monument, the Glory Monument on Stryis'ka Street). Similar processes, affecting urban planning, urban toponyms and symbolic landscapes, transformed Soviet Chernivtsi.

With the end of Soviet rule, the recoding of urban space in Lviv proceeded in several waves. Dismantling of the Lenin monument in 1990, which was the first action of its kind in Ukraine, marked the beginning of the new period. The next step was emphasis on the city's Ukrainian identity 
by renaming streets, ${ }^{4}$ rewriting Russian-language signs into Ukrainian (Hentosh and Tscherkes 259), and unveiling of the monument to Taras Shevchenko in 1992. While the most ideologically loaded Soviet monuments were removed in the 1990s (among them the monument to the communist publicist Yaroslav Halan and the Soviet tank monument on Lychakivs'ka Street), some monuments referring to the Soviet historical narrative remained intact. This included the Pietà composition on the Hill of Glory erected in memory of the fallen Soviet soldiers, and the monumental memorial to the Great Patriotic War on Stryis'ka Street. The subsequent wave of radicalization of memory politics in the 2000s resulted in the Bandera monument and other commemorative initiatives, aimed at contesting the Soviet narrative about the Ukrainian national movement, especially its wartime history. However, despite widespread impressions that the radical nationalist myth dominates symbolic politics in Lviv, elements of Soviet symbolism still coexist in the built environment of the city alongside anti-Soviet narratives.

In Chernivtsi, the break with the Soviet past was not as fast and thorough as it was in Lviv, and the symbolic landscape emerges as more ambivalent and characterized by compromise and avoidance of conflict. While the city's Ukrainian identity has been recognized and emphasized and the most controversial Soviet symbolic markers in the cityscape (e.g., the Lenin statue) were removed early, street names inherited from the Soviet period and monuments dedicated to the Great Patriotic War (e.g., "Nikitin's tank" on Haharyn street) coexist even now with markers inspired by Ukrainian national-liberationist narratives, such as a street and a memory plaque dedicated to the Greek-Catholic Metropolitan Sheptyts'kyi. However, even here efforts of local memory actors to commemorate in the cityscape the most controversial symbolic figures, like the leaders of the OUN-UPA Bandera and Shukhevych, have so far been avoided (although there is a small street named after the latter far from the city centre). Writers and poets like Taras Shevchenko (monument erected in 1999) and Ol'ha Kobylians'ka, who were also included in the Soviet literary pantheon, are preferred to the integral nationalist tradition, which also points to continuity and reinterpretation rather than a sharp break.

Recent efforts to commemorate the dramatic events of the Euromaidan revolution of 2013-2014 led to a new wave of de-Sovietization of urban toponyms in Lviv and Chernivtsi. The decision of the Lviv municipality to change the name of the Soviet-connected Hvardiys'ka Street to Maidan

\footnotetext{
${ }^{4}$ In this connection, some steps have been also taken to draw attention to the city's multicultural history. For instance, together with Russian and Polish street names, three Jewish names appeared on the city map (Hentosh and Tscherkes 264).
} 
Heroes Street (Heroiv Maidanu) raised practically no objections. Meanwhile, in Chernivtsi the situation was more complicated. To begin, the decision to rename not one but three smaller streets was taken without much debate. Thus, Stasiuk Street, named after a Soviet World War II hero, was renamed Heavenly Hundred Street (Nebesnoi Sotni, in honour of the protestors killed by the Yanukovych regime in February 2014 in Kyiv); and the Sovietinspired Chapaev and Frunze Streets were named after local men killed in the protests. However, the long central Red Army Street (Chervonoarmiiska) became Maidan Heroes Street only after debates in which some voices advocated for the historical significance of the existing name. Furthermore, another radical project was undertaken in Chernivtsi during the current wave of Maidan commemorations in May. Greek Catholic CARITAS, adopting an older idea and tying it to a nationalist vision, announced a competition for the best project that would resurrect the Austrian Pietà monument on the Central Square, which had been destroyed by Romanian authorities in the 1920s (Pro pam"iatnyk). According to this initiative, which is supported by the city authorities, the Pietà is intended to commemorate the Heavenly Hundred.

Symbolic de-Sovietization-thorough and effective as it was to varying degrees in both Lviv and Chernivtsi-did not, however, highlight only a Ukrainian national-liberationist narrative. In the collective memories of the present-day population of the two cities, the period of the Habsburg monarchy often emerges as "the good old days of grandma Austria." At first glance, such an attitude to the multinational European empire, where Ukrainians had been loyal second-line subjects, contradicts the current focus on nation building and the "national order of things" (Malkki 495). However, the Austro-Hungarian Empire is also given credit for encouraging cultural institutions of its subject peoples and for allowing political structures to take root that would serve future nation-states. Emperor Franz Joseph I, whose rule extended from the mid-nineteenth century until his death in 1916, is now a respected symbol, embodying the stability of a civilized state and an effective German-style bureaucracy (Hrytsak 2004, 271). After 1991, the positive attitude to, and even nostalgia for, the Danube monarchy has taken on a variety of cultural expressions, particularly in mass culture. Yet, paradoxically, despite a wealth of restaurants referring to the Habsburg period, there is no street named after Franz Joseph and no monument in his honour in Lviv.

On the other hand, an unpretentious monument to Franz Joseph was unveiled in 2009 in Chernivtsi. The Emperor was commemorated as a symbol of Chernivtsi's place in Europe and as a statesman under whose rule the city became an important economic and cultural centre ("Iantseniuk 
zbuduvav..."). Notably, the preparations for erecting the statue were made during the city's $600^{\text {th }}$ anniversary in 2008 in the presence of Karl von Habsburg, a grandson of the last emperor. Arsenii Yatseniuk (born in Chernivtsi), currently Ukraine's Prime Minister and a major political figure since 2005 , funded the monument. It was meant to project a clearly proEuropean political message not only for the city but also for Ukraine as a whole.

A similar official commemoration of the Habsburg ruler proved to be problematic in Lviv, where local political elites prefer to support the image of the city as a centre of Ukrainian political revival. Curiously, although the political elites in Lviv have often been stubbornly focused on more narrow Ukrainian projects, cultural and creative elites have no problem exploiting the multicultural ambience of the city in their commemorative initiatives. For example, the highbrow "independent cultural" Lviv magazine Ji (i), published a special issue titled Franz Joseph I. Privately (Frants Iosef I. Pryvatno), confirming thereby the current trend of making the last Habsburg a prominent symbolic figure. However, the most original initiative to commemorate Franz Joseph I came recently from a milieu gathered around an incubator of artistic initiatives, Museum of Ideas, founded by the Lviv artist Oles' Dzyndra. To celebrate the last emperor of Austria-Hungary, artists participating in a project titled Monument to Memory created a three-dimensional drawing of the young emperor's bust for the purpose of moulding it in bronze. However, to see the bust realized, Lvivites were first asked to purchase special coins with the Emperor's image, and then, at a fixed date, to bring them to the museum for melting and moulding. In other words, the Emperor's bust will adorn one of Lviv's streets only if people make a concerted effort-even a sacrifice-to spotlight the city's multicultural and European past. According to the project's website, so far only 32 people, mostly the intelligentsia, have bought the coins. Obviously, this not enough to begin preparations for a casting ceremony ("Art-proekt Olesia Dzyndry").

In Chernivtsi there were similar commemorations of the Habsburg period, initiated by cultural and intellectual circles. As an example, we can cite a sculptural composition dedicated to the proverbial roses that, in the words of a contemporary German poet, once swept the streets of old Czernowitz. This sculpture was inaugurated during the $600^{\text {th }}$ anniversary celebrations in 2008 on a wall outside the Literatur-Café located on the Central Square. During the celebrations, "pop-cultural" monuments, referring to material progress, individual prosperity and the "European" life-style of the Habsburg era, were also unveiled. For example, the city's first bicycle was portrayed on Turkish Square, as well as a bronze carriage 
on fashionable Kobylians'ka Street. As in Lviv, several commercial enterprises (hotels, restaurants and cafés) also celebrated the Habsburg period and the Kaiser himself.

Another post-Soviet trend that came in the wake of interest in the Habsburg period and unfolded in tandem with the symbolic Ukrainization of both cityscapes, is the interest of the wider public in recovering memory of the ethnically and culturally "others." This trend is, however, not fully coterminous with western-style practices of acknowledgement and celebration of difference. According to a survey conducted in Lviv ("Ievreis'ka spadshchyna..."), contemporary Lvivites appreciate initiatives that enhance popular knowledge of the vanished ethno-cultural diversity but are much less positively disposed to permanently re-marking of public places with references to the military glory, suffering and martyrdom of other nations. Initiatives and funding of most monuments, plaques, small statues and other commemorative symbols that refer to the Polish, Jewish and Armenian presence still come primarily-in arrangement with the municipality-from diaspora and minority communities (Dyak), from international organizations or private persons. Some statues (e.g., of Leopold von Sacher-Masoch; of Jan Zeg and Ignacy Łukasiewicz, inventors of the gas lamp; of soldier Schweik; of Romualdo and Palagna, the local Romeo and Juliet) are installed as tourist magnets in the vicinity of some cafes in the downtown. However, among serious commemorative initiatives one may mention the opening in 2005 of the restored Polish military Pantheon (known as Lwów Eaglets Cemetery), and the unveiling in 2012 of the monument to Polish professors executed by the Nazis in 1941. The latter project was a partnered initiative of the municipal governments and the universities of Lviv and Wrocław. The intellectual milieus, academic institutions and museums have also followed the trend. Among the successful academic-intellectual initiatives of the last decade one should mention a series by the journal Ji devoted to the multicultural "universes" of Western Ukraine, including an issue on Chernivtsi, and exhibitions on the multicultural history of Lviv organized by the Centre for Urban History of East Central Europe.

In post-Soviet Chernivtsi renewed interest in the city's prewar communities has often been articulated in the framework of local and transnational narratives celebrating the city's ethno-cultural diversity (see e.g., Koziura 2014). The term "Bukovynian tolerance" is often used as a catchphrase in both intellectual and everyday contexts, signifying the relatively relaxed inter-ethnic relations between the traditional local communities (Ukrainian, Romanian, German, Jewish, Polish and Armenian). This discourse of tolerance is widely perceived to have been fostered in the Habsburg era, and is used to assert the status of Chernivtsi as a European 
city (Bernsand, forthcoming). Interestingly, several of our interviewees from Chernivtsi favourably compared what they saw as tolerant interethnic relations in Chernivtsi and Bukovyna with the arguably more tense inter-communitarian relations in Lviv and Galicia.

The local ethnic community organizations (natsional'no-kulturni tovarystva) are in various ways integrated into the work of municipal authorities and play an active role in memory initiatives. However, as in Lviv, transnational organizations and private persons are important for initiating, funding and maintaining the memories of the dwindling ethnocultural communities (i.e., other than the Ukrainian and Romanian) in public spaces. Significantly, the prewar national houses (narodni domy) of ethnic communities in central locations of the city have been returned to reestablished community organizations for their use. Other recent examples of the commemoration of the local "others" in public space are the monuments to the German-language Jewish poet Paul Celan (erected in 1992) and Romanian poet Mihai Eminescu (erected in 2000), as well as memorial plagues to Yiddish writer Eliezer Steinbarg, Jewish singer Sidi Tal, long-time ethnic Polish mayor Anton von Kochanowski, Armenian musician Karol Mikuli and Romanian composer Ciprian Porumbescu. Among other recurring notable initiatives sponsored by both local and transnational actors is the yearly Meridian Czernowitz festival that gathers mainly Ukrainian and German-language writers, poets and artists in the city. The festival actively relates to the German-language and Jewish prewar local intellectual culture. The yearly folkloric festival Bukovynian Meetings (Bukovyns'ki zustrychi), initiated by the Polish community, also has the function of showcasing to wider audiences the presence of now mostly exiled Bukovynian ethno-cultural communities, albeit in stylized and rural versions. Nevertheless, for the majority of urbanites these manifestations of a largely vanished prewar ethnic diversity are at best prosthetic memories charged with past potentialities.

Finally, contemporary European narratives that decentre heroization of military activities and focus instead on losses and suffering have increasingly influenced memories about World War II in both Lviv and Chernivtsi. ${ }^{5}$ After 1991, the tragic fate of the large Jewish community has been acknowledged, with Jews being distinguished from "Soviet citizens" as a special group of victims. Even so, the argument about anti-Semitism as an ideological platform of the OUN-UPA and the question of Ukrainian

5 For more about European commemorative frameworks and principles underpinning debates on a common European memory see, for example, Malksöö; Pakier and Stråth; Leggewie; Sierp. 
nationalist militias collaborating with the Nazis in mass killings of Jews still remains hotly debated (Himka; Rudling).

In Lviv, the first initiative to commemorate the Jewish inhabitants who perished in the Holocaust came from the local Sholom Aleikhem Jewish Culture Society as early as 1988. Late Soviet documentation pertaining to the monument's construction mostly spoke of the "Monument in Pelekhatoho Street" rather then of a monument to the victims of the Jewish ghetto or the Holocaust. Whether consciously or not, the idea of commemorating the Jewish victims was downplayed in official documents (Yakovleva). Disputes between Jewish activists and the then Soviet city administration, which initially suggested that the Holocaust monument be located far away from the city centre, exposed a certain strategy that since the 1980s periodically comes to light in connection with other memory debates-for example, on the Lwów Eaglets Cemetery and the Polish House (Narvselius, forthcoming). This tendency is not a denial of the symbolical presence of "others" and their difficult histories. It is rather an attempt by local authorities to play the role of gatekeepers who define the conditions under which the non-Ukrainian component will be commemorated in Lviv. Nevertheless, after fundraising among the Jewish diaspora and Lviv residents, the monument to the victims of the Lviv ghetto was eventually opened in 1992-and not in Pelekhatoho Street on the outskirts of the city but in the downtown, on the territory of the former ghetto, in the presence of survivors, politicians and invited honoured guests from abroad. Not long after this, a sign commemorating victims of Soviet totalitarianism, with a cross in the composition, was opened just across the street.

By and large, the history of the post-1991 commemoration of Jewish culture and the Holocaust in Lviv includes a series of successful initiatives. As for landscape design and architecture, one should mention the recent international competitions Synagogue Square Site, Besojlem Memorial Park Site, and Yanivs'kii Camp Memorial Site aiming to draw attention to the vacuum and "non-places" left after the extermination of the prewar Jewish community. When it comes to educational initiatives, a training program for specialists in the history and culture of the Jewish people, launched by Ivan Franko National University of Lviv in 1992 (Yakovleva), stands out as the first of its kind in Ukraine. Furthermore, cultural and commercial actors have popularized Jewish culture. Among their initiatives are the annual international festival of Jewish music LvivKlezFest initiated in 2008; thematic issues of the magazine Ji (2007 and 2008); and an annual summer school on Jewish history and culture at the Centre for Urban History of East Central Europe, to mention just a few. However, due to legislative complications around items of Jewish heritage and for a simple lack of 
premises and money (Mur), only a fraction of the rich collections of Judaica stored in Lviv's History of Religion Museum and the Ethnography Museum has ever been exhibit in the city and abroad. Also, throughout the 2000s, Jewish memory and heritage was primarily a concern of local Jewish organizations, their partners from the Jewish Diaspora (Dyak) or other international organizations. Both official discourse and public opinion (see "Ievreiska spadshchyna...") do not fully recognize the Jewish heritage of the city as an important cultural asset. Even though it needs to be treated with great care due to its fragility, it deserves broader promotion and exhibition, free from intentional censorship and stereotyping. (The latter is especially obvious when Jewishness is explained to tourists.) Partly because of such attitudes, one comes across cases of insensitive use of Jewish symbols for commercial purposes. For instance, in the Galician Jewish Restaurant Under Golden Roza (Halyts'ka zhydivs'ka knaipa Pid Zolotoiu Rozoiu) visitors have been encouraged to haggle and to try on hats decorated with Jewish sidelocks. On the other hand, people tend to painstakingly avoid speaking about the involvement of Ukrainian nationalist forces in the extermination of Jews during World War II. Emphasis is placed on how Ukrainians, especially the Greek-Catholic clergy, rescued Jews. (This is currently evident in the newly opened Jewish Museum on the Staroievreis'ka Street).

While the darker aspects of the history of the "others" in Chernivtsi are not denied and public commemoration is not discouraged, the forms of such commemoration, as in Lviv, are the result of negotiations in which the municipal authorities often act as gatekeepers. Two monuments to the victims of the Holocaust (one placed at the outskirts of the city in 1990, the other placed in the downtown premises of the transnational Jewish organization Hesed Shushana in 2000) came into existence at the initiative of local and transnational Jewish activists (Kushnir; Fuks; See also Osachuk et. al. 50, 71). Efforts by local Jewish actors to raise a monument to the Holocaust victims in the former ghetto in the city centre have, however, so far been unsuccessful. Apart from disagreements between Jewish and Romanian activists on the proper textual message for the monument, the city council was willing to grant permission only if the Jewish community financed the monument independently, since the monument was considered of interest, first and foremost, to the Jewish community. Therefore the process has so far come to a halt (Kushnir). Concurrently, city dignitaries always take part in the official commemoration of the Holocaust. This suggests that local memory culture in both cities is characterized by the pillarization of memory (Ashworth, Graham and Tunbridge 82-84), i.e., each community is supposed to initiate, finance and maintain "its own" commemoration. In this respect, the Jewish Museum in Chernivtsi, located on the first floor in the Jewish National House, plays an important role since 
it was opened on private initiative in 2008. The museum showcases the life of the prewar local Jewish community and its dismemberment during the Holocaust. The museum cooperates with transnational funds and research institutions especially to maintain the old Jewish cemetery on Zelena Street, which is done with the help of young volunteers from Western Europe. This institution is also an important actor in efforts to conceptualize the Holocaust as a relevant experience not only for the Jewish ethnic community but for all inhabitants of the city.

Another example of pillarization is the memory plaque to Romanian mayor Traian Popovici, who is celebrated for saving the lives of up to 20,000 Jews. It was installed in cooperation with the Chernivtsi Diaspora Jewish community of New York and local Jews ("Meru, iakyi vriatuvav..."). Nevertheless, the negative reaction from Romanian activists in Chernivtsi (they resented the portrayal of Romanians as culprits in the extermination of local Jews during the German-Romanian occupation of 1941-1944) shows that the memory actors in Chernivtsi are aligned in a more complex relationship than those in Lviv.

\section{DISCUSSION AND CONCLUSIONS}

The examples mentioned above of commemorative practices demonstrate that cultures of memory in the two cities share at least two basic features. Firstly, they transmit enduring narratives about the acceptance or denial of ethno-cultural diversity. Secondly, they disclose a strong relationship of contemporary urban populations to the past, a relationship actualized by means of performativity, selective remembering, counter-memories and nostalgia. Attitudes toward the city's past among a great majority of urbanites are formed not through personal experience and familial transfer of post-memories, but rather through prosthetic memory that relies on hearsay, media, literature, popular culture and the arts. When the issue of selecting a particular past comes to the fore, the work of stitching together various, often contradictory, historical representations for purposes of various identity projects is guided not so much by path-dependent logic of collective memory, as by present-day expediency and power games of different mnemonic actors. Therefore, we would argue, that the third similarity between Lviv and Chernivtsi in terms of cultures of memory is pillarization, i.e., a basic agreement by both external and internal memory entrepreneurs and marketeers (Huyssen 20) that every population group is a custodian of its own heritage.

Meanwhile, our material also indicates the existence of dissimilar cultures of memory in Lviv and Chernivtsi, which highlight issues of political mobilization, cultural affinity and ethno-cultural diversity in quite 
different ways. What are the possible factors and sources of difference in the memory cultures circulating in Lviv and Chernivtsi? As of this writing, we can point to several plausible explanations.

\section{1) The Political Hierarchy of Minorities}

Throughout history, Chernivtsi has been home to a large number of national and cultural-religious groups whose share in the overall structure of the urban population did not allow them to claim a leading position. No single ethnic group has been politically, economically and culturally hegemonic at the same time. In Lviv, however, rivalry between two large national groups-Poles and Ukrainians-was evident throughout modern history. Partly because of this, current attitudes toward local minorities and their cultural claims is more relaxed in Chernivtsi, while in Lviv they are more sceptical and questioning. Furthermore, the contemporary presence of ethnic minorities in Chernivtsi is also comparatively larger, with Romanians in 2001 representing 6 percent of the urban population. The surrounding Chernivetska oblast' also has a heavy minority presence, with Romanians and Moldavians comprising 20 percent of the population. Moreover, Romanians are often found in important political and administrative positions in the city.

\section{2) Power Relations among Post-1991 Local Political Elites}

In both Lviv and Chernivtsi the city council and (on some questions) the oblast' council have a decisive role in formulating priorities of local memory politics and promotion of commemorative initiatives. If in Lviv national democrats (and, presently, radical right-wing nationalists) play a leading role, in Chernivtsi, the local political scene has de-Sovietized more slowly, meaning national democrats have not been as consistently dominant in the political sphere.

\section{3) Integration of Intellectual Discussion into a "Western" Paradigm}

In addition to several academic institutions with a long history, Lviv has a number of newly established independent intellectual milieus and academic arenas that are not only massively involved in international cooperation, but also transmit the standards of "Western" academic work. Intellectual discussions about the difficult past and historical ethno-cultural diversity in Western Ukraine, initiated by these milieus, have not only increased public awareness of the topic, but also influenced the political discourse. Nevertheless, it must be admitted that most of the accumulated knowledge remains confined to academic and highbrow cultural circles, and does not impede the established Ukraine-centred patterns of commemoration. In Chernivtsi, thus far, there are no influential independent milieus engaged in the multicultural past. Nor do they have transnational connections comparable to the magazine Ji and the Centre for 
Urban History of East Central Europe in Lviv, although the now defunct Bukowina Zentrum did have such a function. Presently both the Zentrum Gedankendach at Yurii Fed'kovych University and the annual international poetry festival, Meridian Czernowitz, shed light on the city's Germanlanguage past in cooperation mostly with German and Austrian partners.

4) Transnational and Transcultural Connections on the Level of Elites

The political and cultural elites of Lviv and Chernivtsi are involved in international/transnational co-operation to different degrees. The contact of Lviv elites with international investors, foreign NGOs, academic communities, artistic milieus, and municipalities all over the world have grown exponentially throughout the years of Ukraine's independence. Notwithstanding growth in the post-Soviet period, the scale and intensity of such contacts in Chernivtsi are comparatively smaller, probably because of the city's smaller size, weaker economic infrastructure and more peripheral location. In future studies, the present authors will look closer at practices, discourses and attitudes of the local elites engaged in the revitalization of the architectural environments and in the reinvention of the past as a significant symbolic resource.

5) Commercialization of the Past

The authors discovered that the public imagery concerning the past is strongly influenced in the two cities by the entrepreneurial activities of local enthusiasts who have taken a lead not only in popularizing and commercializing it, but also in reimagining the available memory representations in more radical ways. Chernivtsi-because of its poor communication infrastructure and location away from the main tourist routes (not to mention its comparably modest branding campaigns and advertising) - is less developed than Lviv in this respect. Add to this the quality of the cultural elites, the vicissitudes of local memory politics and the result is that the rich cultural heritage of the proverbial "Little Vienna" has not become an object of commercialization and commodification to the extent as did Lviv's.

One of our conclusions is that the perceived differences between the two urban memory cultures have much to do with different attitudes (on both the popular and elite level) toward post-1989 Ukrainian nation building. Different perspectives on what constitutes the essence of the 'national' predetermine differences in commemorative practices and narratives on diversity versus homogeneity. While the memory culture of contemporary Lviv associates the city with being the "Ukrainian Piedmont," which is instrumental in establishing a politicized, mobilized and essentially anti-Soviet vision of the national identity, Chernivtsi betrays a more culturally muted outlook that in some respects is a vestige of wellestablished Soviet views on nationality, as something primarily ethno- 
cultural. For this reason, the attitude toward, and the practice of working with, different "pillars" (i.e., memories of different population groups) in Lviv and Chernivtsi vary.

If we now shift our focus from vibrant commemorative practices and performances to heritage policies, we can register a fundamental similarity between memory cultures of our two cities. A basic characteristic of heritage is its conditional mood: "...heritage is envisaged as having moved along a continuum from the preservation of what remains, to the maintenance, replacement, enhancement and facsimile construction of what might, could or should have been" (Ashworth, Graham and Tunbridge 26). Much of our evidence indicates that, given the heritage being promoted in the two cities, they envisage and highlight not a pillar model, but rather an assimilationist "incorporation-to-the-core" model, where the core is understood to be the various versions of Ukrainian national heritage. It is not difficult to notice that the commercialized representations of Lviv's and Chernivtsi's multicultural past are directed for the most part at external audiences (tourists, diasporas, descendants of former inhabitants), while the local population is expected to identify with another, i.e., the Ukrainian heritage. Such construction of a "double heritage" exemplifies assimilationist logic. As Ashworth, Graham and Tunbridge remind us:

A not uncommon variant of this [assimilationist model-E.N.,N.B.] should be noted, namely the two-dimensional model where two different public heritages are presented in parallel, the one for external and the other for internal consumption. There is no conflict or tension in this bipolarity, which is not an expression of two societies but only of a single society narrated in different ways to different markets. This is especially evident in postcolonial countries engaged simultaneously in local nation-building and attempts to position themselves within global economic and social systems (75).

Such assimilationist logic is hardly inevitable in Lviv and Chernivtsi, where one also finds examples of respectful, sensible and delicate memory work among present-day urbanites. At the moment, however, this logic dominates the memory cultures of Lviv and Chernivtsi.

\section{Works Cited}

Aronsson, Peter, and Lizette Grandén, eds. Performing Nordic Heritage. Everyday Practices and Institutional Culture. Farnham: Ashgate, 2013. Print.

"Art-proekt Olesia Dzyndry 'Pam"iatnyk Frantsu-Iosyfu I u L'vovi.'” Muzei idei. Web. July 13, 2014. <http://idem.org.ua/fy/index.html>.

Ashworth, Gregory J., Bryan Graham and J.E. Tunbridge. Pluralising Pasts: Heritage, Identity and Place in Multicultural Societies. London: Pluto Press, 2007. Print.

Assman, Aleida. "Ghosts of the Past." East European Memory Studies 8 (2011): 1-5. Print. 
Assmann, Jan. "Globalization, Universalism, and the Erosion of Cultural Memory." Memory in a Global Age. Discourses, Practices and Trajectories. Ed. Aleida Assmann and Sebastian Conrad. New York: Palgrave Macmillan, 2010. 121-37. Print.

---. Cultural Memory and Early Civilization. Writing, Remembrance, and Political Imagination. Cambridge: Cambridge University Press, 2011. Print.

Bartov, Omer. Erased: Vanishing Traces of Jewish Galicia in Present-Day Ukraine. Princeton and Oxford: Princeton University Press, 2007. Print.

Basu, Peter. "Memoryscapes and Multi-Cited Methods." Research Methods for Memory Studies. Eds. Emily Keightley and Michael Pickering. Edinburgh: Edinburgh University Press, 2013. 115-31. Print.

Bernsand, Niklas (forthcoming). "Memories of Ethnic Diversity in Local Newspapers: the 600th Anniversary in Chernivtsi." Remembering Ethnic Cleansing and Lost Cultural Diversity in Central and Eastern European Cities. Ed. Barbara Törnquist-Plewa. Oxford and New York: Berghahn Books. 2015. Print.

Blacker, Uilleam. "Living among the Ghosts of Others: Urban Postmemory in Eastern Europe." Memory and Theory in Eastern Europe. Eds. Uilleam Blacker, Alexander Etkind and Julie Fedor. New York: Palgrave Macmillan, 2013. 173-93. Print.

Blacker, Uilleam, and Alexander Etkind. "Introduction." Memory and Theory in Eastern Europe. Eds. Uilleam Blacker, Alexander Etkind and Julie Fedor. New York: Palgrave Macmillan, 2013. 1-22. Print.

Certeau, Michel de. The Practice of Everyday Life. Trans. Steven Rendall. Berkeley: University of California Press, 1984. Print.

Confino, Alan. Germany As a Culture of Remembrance: Promises and Limits of Writing History. Chapel Hill: UNC Press Books, 2006. Print.

Czaplicka, John. "Lviv, Lemberg, Leopolis, Lwów, Lvov: A City in the Crosscurrents of European Culture." Lviv: A City in the Crosscurrents of Culture. Ed. John Czaplicka. Spec. issue of Harvard Ukrainian Studies 24 (2002): 13-47. Print.

Dyak, Sofia. “'Diaspora Battlefield': Commemorative and Heritage Projects in Lviv after 1991." 19-21 Apr. 2012, ASN World Convention, Columbia University. Unpublished conference paper, 2012.

Erll, Astrid. "Travelling Memory." Parallax 17.4 (2011): 4-18. Print.

Feindt Gregor, Félix Krawatzek, Daniela Mehler, Friedemann Pestel, and Rieke Trimçev. "Entangled Memory: Toward a Third Wave in Memory Studies," History and Theory 53 (2014): 24-44. Print.

Follis, Karolina. Building Fortress Europe: The Polish-Ukrainian Frontier. Philadelphia: Pennsylvania University Press, 2012. Print.

Frunchak, Svetlana. "Commemorating the Future in Post-War Chernivtsi." East European Politics and Societies 24.3 (2010): 435-463. Print.

Fuks, Leonid, director of Chernivtsi Hesed Shoshana. Personal interview by Niklas Bernsand. 14 June 2013.

Graham, Brian and Peter Howard. "Heritage and Identity." The Ashgate Research Companion to Heritage and Identity. Eds. Brian Graham and Peter Howard. Aldershot: Ashgate, 2008. 2-15. Print.

Hentosh, Liliana and Bohdan Tscherkes. "L'viv in Search of Its Identity: Transformations of the City's Public Space." Cities after the Fall of Communism. Reshaping Cultural Landscapes and European Identity. Ed. John Czaplicka, Nida Gelazis and Blair A. Ruble. Baltimore: The John Hopkins University Press, 2009. 255-79. Print. 
Himka, John-Paul. "Ukrainian Collaboration and Extermination of the Jews during World War II: Sorting Out the Long-Term and Conjunctional Factors." The Scrolls 3.16 (1999). Web. <www.zwoje-scrolls.com/zwoje16/text11.ht>.

Hirsch, Marianne. "The Generation of Postmemory." Poetics Today 29.1 (2008): 103-128. Print.

Hirsch, Marianne and Leo Spitzer. The Ghosts of Home: The Afterlife of Czernowitz in Jewish Memory. Berkley and Los Angles: University of California Press, 2010. Print.

Hrytsak, Yaroslav. "L'viv: A Multicultural History through the Centuries." Lviv: A City in the Crosscurrents of Culture. Ed. John Czaplicka. Spec. issue of Harvard Ukrainian Studies 24 (2002): 47-74. Print.

---. Strasti za natsionalizmom: Istorychni esei. Kyiv: Krytyka, 2004. Print.

---. "Historical Memory and Regional Identity among Galicia's Ukrainians." Galicia: A Multicultured Land. Eds. Christopher Hann and Paul R. Magocsi. Toronto: University of Toronto Press, 2005. 185-209. Print.

Huyssen, Andreas. Present Pasts: Urban Palimpsests and the Politics of Memory. Stanford: Stanford University Press, 2003. Print.

"Iatseniuk na svoi hroshi zbuduvav pam"iatnyk Frantsu-Iosyfu." A.C.D. Ahenstvo stratehichnykh doslidzhen'. Web. 4 October 2009. <http://sd.net.ua/2009/10/04/ jacenjuk_zbuduvav_pamjatnik_imperatoru_francujjosi.html>.

“Ievreis'ka spadshchyna L'vova. Rezul'taty sotsiolohichnoho doslidzennia, provedenoho Tsentrom mis'koi istorii Tsentral'no-Skhidnoi Ievropy spil'no $\mathrm{z}$ ahentstvom Socinform." October 2008. The Centre for Urban History of East Central Europe (Lviv). Unpublished presentation.

Kansteiner, Wulf. "Finding Meaning in Memory: A Methodological Critique of Collective Memory." History and Theory 41.2 (2002): 179-197. Print.

Koziura, Karolina. "Everyday Ethnicity in Chernivtsi, Western Ukraine." Anthropology of East Europe 1.32 (2014): 1-21. Print.

Kushnir, Mykola, director of the Chernivtsi Museum of the History and Culture of Bukovynian Jews. Personal interview by Niklas Bernsand. 17 April 2013.

Landsberg, Alison. Prosthetic Memory: The Transformation of American Remembrance in the Age of Mass Culture. New York: Columbia University Press, 2004. Print.

Leggewie, Claus. Der Kampf um die europäische Erinnerung: Ein Schlachtfeld wird besichtigt. Munich: Verlag C.H. Beck, 2011. Print.

Lévy, Daniel, and Natan Sznaider. The Holocaust and Memory In The Global Age. Philadelphia: Temple University Press, 2006. Print.

Lihaciu, Ion. Czernowitz 1848-1918: Das kulturelle Leben einer Provinzmetropole. Mehlingen: Parthenon Verlag, 2012. Print.

Malkki, Liisa H. "Refugees and Exile: From 'Refugee Studies' to the National Order of Things." Annual Review of Anthropology 24 (1995): 495-523. Print.

Martin, Terry "An Affirmative Action Empire: The Soviet Union as the Highest Form of Imperialism." A State of Nations: Empire and Nation-Making in the Age of Lenin and Stalin. Eds. Ronald Grigor Suny and Terry Martin. Oxford: Oxford University Press, 2001. 67-90. Print.

"Meru, iakyi vriatuvav 20 tysiach ievreiv, vstanovyly doshku." Molodyi bukovynets'. 21 Apr. 2009. Web. 13 July 2014. <http://molbuk.ua/news/19465-meru-jakijj-vrjatuvav-20tisjach-yevreyiv.html>.

Mink, Georges. "Between Reconciliation and the Reactivation of the Past Conflicts in 
Europe: Rethinking Social Memory Paradigms." Czech Sociological Review 44.3 (2008): 469-90. Print.

Misztal, Barbara. "Collective Memory in a Global Age. Learning How and What to Remember." Current Sociology 58.1 (2010): 24-44. Print.

Mur, Daryna. "Na ievreis'kyi muzei brakuie hroshei." Galinfo. 15 June 2009. Web. 13 July 13, 2014. <http://galinfo.com.ua/news/51875.html>.

Mälksoo, Maria. "The Memory Politics of Becoming European: The East European Subalterns and the Collective Memory of Europe." European Journal of International Relations 15.4 (2009): 653-680. Print.

Narvselius, Eleonora (forthcoming). "Polishness as a Site of Memory and Arena for Construction of a Multicultural Heritage in Lviv." Remembering Ethnic Cleansing and Lost Cultural Diversity in Central and Eastern European Cities. Ed. Barbara TörnquistPlewa. Oxford and New York: Berghahn Books, 2015. Print.

Olick, Jeffrey K. The Politics of Regret: On Collective Memory and Historical Responsibility. New York and London: Routledge, 2007. Print.

Osachuk, Serhiy, Volodymyr Zapolovs'kyi and Nataliya Shevchenko. Pamyatnyky Chernivtsiv/Denkmäler von Czernowitz. Chernivtsi: Zelena Bukovyna, 2009. Print.

Pakier, Malgorzata and Bo Stråth, eds. A European Memory? Contemporary Histories and Politics of Remembrance. New York: Berghahn Books, 2010. Print.

Peckham, Robert Shannan. "The Politics of Heritage and Public Culture." Rethinking Heritage. Cultures and Politics in Europe. Ed. Robert Shannan Peckham. London: I. B. Tauris, 2003. 1-16. Print.

Phillips, Kendall R. and G. Mitchell Reyes, eds. Global Memoryscapes: Contesting Remembrance in a Transnational Age. Alabama: The University of Alabama Press, 2011. Print.

Prokopovych, Markian. Habsburg Lemberg: Architecture, Public Space and Politics in the Galician Capital, 1772-1914. West Lafayette: Purdue University Press, 2008. Print.

"Pro pam"iatnyk Pieta u Chernivtsiakh." Ofitsiinyi web-portal Chernivets'koi mis'koi rady. Web. 3 June 2014. <http://chernivtsy.eu/portal/4/pro-pam-yatnykpiyeta-u-chernivtsyah-53240.html>.

Radstone, Susannah and Katharine Hodgkin. "Regimes of Memory: An Introduction." Regimes of Memory. Eds. Susannah Radstone and Katharine Hodgkin. London: Routledge, 2003. 1-22. Print.

Risch, William Jay. The Ukrainian West: Culture and the Fate of Empire in Soviet Lviv. Cambridge, MA: Harvard University Press, 2011. Print.

Rothberg, Michael. Multidirectional Memory: Remembering the Holocaust in the Age of Decolonization. Stanford: Stanford University Press, 2009. Print.

Rudling, Per Anders. "The OUN, the UPA and the Holocaust: A Study in the Manufacturing of Historical Myths." Carl Beck Papers 2107 (2011): 1-71. Print.

Sherlock, Thomas. Historical Narratives in the Soviet Union and Post-Soviet Russia: Destroying the Settled Past, Creating an Uncertain Future. New York: Palgrave Macmillan, 2007. Print.

Sierp, Aline. History, Memory, and Trans-European Identity: Unifying Divisions. London and New York: Routledge, 2014. Print.

Slezkine, Yuri. "The USSR as a Communal Apartment, or How a Socialist State Promoted Ethnic Particularism." Slavic Review 53.2 (1994): 414-52. Print.

Snyder, Timothy. Bloodlands: Europe Between Hitler and Stalin. Basic Books, 2010. Print. 
Ther, Philipp. "War versus Peace: Interethnic Relations in Lviv during the First Half of the Twentieth Century." Lviv: A City in the Crosscurrents of Culture. Ed. John Czaplicka. Spec. issue of Harvard Ukrainian Studies 24 (2002): 251-84. Print.

Tilmans, Karin, Frank van Vree, and Jay Winter. "Preface." Performing the Past. Memory, History, and Identity in Modern Europe. Eds. Karin Tilmans, Frank van Vree and Jay Winter. Amsterdam: Amsterdam University Press, 2010. 7-8. Print.

Tscherkes, Bohdan. "Stalinist Visions for the Urban Transformation of L'viv, 1939-1955." Lviv: A City in the Crosscurrents of Culture. Ed. John Czaplicka. Spec. issue of Harvard Ukrainian Studies 24 (2002): 205-22. Print.

Winter, Jay. "Introduction. The Performance of the Past: Memory, History, Identity." Performing the Past. Memory, History, and Identity in Modern Europe. Eds. Karin Tilmans, Frank van Vree and Jay Winter. Amsterdam: Amsterdam University Press, 2010. 11-23. Print.

Yakovleva, Victoria. "Prosp. Chornovola-Lviv Ghetto Victims Memorial." Tsentr mis'koi istorii Tsentral'no-Skhidnoi Ievropy. Web. 13 July 2014. <http:// www.Lvivcenter.org/en/lia/description/?ci_objectid=224>.

Zayarniuk, Andriy. "On the Frontiers of Central Europe: Ukrainian Galicia at the Turn of the Millennium." Spaces of Identity 1 (2001): 15-34. Web. 13 July 2014. <https:// pi.library.yorku.ca/ojs/index.php/soi/article/view/8053/7231>. 
